Jurnal Kesehatan Terpadu (Integrated Health Journal)

Vol. 12 No. 1, Mei 2021 (30-38)

ISSN 1978-7766 (Print) and ISSN 2597-9566 (Online)

Journal homepage: https://www.jurnalpoltekkesmaluku.com/index.php/JKT

\title{
Pengaruh Inisiasi Menyusu Dini terhadap Pengeluaran Volume ASI pada Primipara \\ di Rumah Sakit Tk II Prof. Dr. J. A. Latumeten dan RSUD Dr. M. Haulussy Ambon \\ The Effect of Early Breastfeeding Initiation on Production of Breastmilk Volume in Primipara at Rumkit Tk.II Prof Dr. J. A. Latumeten and RSUD Dr. M. Haulussy Ambon
}

\author{
Sitti Suharni Hermanses ${ }^{1}$, Fasiha ${ }^{2}$ \\ ${ }^{1}$ Prodi Kebidanan Saumlaki Poltekkes Kemenkes Maluku, Jalan Suster Makari, Saumlaki, \\ Kabupaten Kepulauan Tanimbar \\ ${ }^{2}$ Jurusan Kebidanan Ambon Poltekkes Kemenkes Maluku, Jalan Laksdya Leo Wattimena, \\ Negeri Lama, Ambon \\ E-mail Korespondensi: suharni.hermanses@gmail.com
}

\begin{abstract}
Early initiation of breastfeeding is an effort to provide colostrum which is rich protective factors. This study aimed to determine the effect of early initiation of breastfeeding on breastmilk volume. This research use quasi experimental. The results showed that the Mann-Whitney test obtained a value of $\mathrm{p}=0.000<$ of $\alpha=0.05$, there was an effect on breastmilk volume in mothers who did early initiation of breastfeeding. Implementation of early initiation of breastfeeding in case group was $100 \%$ otherwise not done in control group, the duration $64 \%$ hasn't been standardized, the breastmilk volume on the third day after early breastfeeding initiation was categorized sufficient $(56 \%)$ and a lot $40 \%$, which was not $76 \%$ breastmilk volume is lacking, there is a difference on breastmilk volume in mothers who have early initiation of breastfeeding and do not have. There is an effect on breastmilk production. It is expected that the role of midwives in providing information to mothers before giving birth about the importance of early breasfeeding initiation. It is expected that midwives will emphasize more on the duration of skin to skin contact, according to minimum standards of 1 hour, Rumkit Tk II Prof. Dr. J.A. Latumeten is expected to do early initiation of breastfeeding as a fixed procedure in the maternity room.
\end{abstract}

\section{Keywords: Breastmilk, early initiation of breastfeeding, volume}

\begin{abstract}
ABSTRAK
Inisiasi Menyusu Dini (IMD) adalah upaya pemberian kolostrum yang merupakan makanan terbaik dengan nutrisi yang sempurna dan mengandung zat kekebalan 10-17 kali lebih banyak dari susu matur. Penelitian ini untuk mengetahui pengaruh IMD terhadap pengeluaran Volume ASI. Jenis penelitian adalah quasi eksperimental. Hasil dengan Mann-Whitney test diperoleh nilai $p=0.000<$ dari $\alpha=0.05$, artinya ada pengaruh pengeluaran volume ASI pada ibu yang melakukan IMD. Pelaksanaan IMD pada kelompok kasus adalah 100\% sebaliknya tidak dilakukan pada kelompok kontrol, lama waktu pemberian IMD, 64\% belum sesuai standar, volume pengeluaran ASI pada hari ketiga setelah IMD dikatagorikan cukup (56\%) dan banyak 40\%, yang tidak IMD 76\% volume ASI kurang, terdapat perbedaan volume ASI pada ibu yang IMD dan tidak IMD, terdapat pengaruh pengeluaran ASI pada ibu yang melakukan IMD dan tidak melakukan IMD. Diharapkan peran bidan dalam memberikan informasi kepada ibu sebelum melahirkan pentingnya IMD dan proses pelaksanaannya dengan memberdayakan mahasiswa Kebidanan, Keperawatan dan Kedokteran yang sedang praktik untuk mensosialisasikan keberhasilan IMD. Diharapkan bidan lebih menekankan IMD bukan pada pencapaian puting susu tetapi lama kontak skin to skin, sesuai standar minimal yaitu 1 jam, Rumkit Tk II Prof. Dr. J. A. Latumeten diharapkan dapat melaksanakan IMD sebagai salah satu prosedur tetap di kamar bersalin.
\end{abstract}

Kata kunci: ASI, Inisiasi Menyusu Dini, volume 
Jurnal Kesehatan Terpadu (Integrated Health Journal)

Vol. 12 No. 1, Mei 2021 (30-38)

ISSN 1978-7766 (Print) and ISSN 2597-9566 (Online)

Journal homepage: https://www.jurnalpoltekkesmaluku.com/index.php/JKT

\section{PENDAHULUAN}

Inisiasi Menyusu Dini (IMD) adalah upaya pemberian kolostrum yang merupakan makanan terbaik dengan nutrisi yang sempurna dan mengandung zat kekebalan 10-17 kali lebih banyak dari susu matur ${ }^{1}$. Satu jam pertama setelah bayi lahir adalah kesempatan emas yang akan menentukan keberhasilan ibu untuk menyusui bayinya secara optimal, karena bayi sudah terlatih secara naluriah menemukan sendiri puting susu ibunya. Bayi yang bisa menyusu dalam 20-30 menit akan membantu bayi memperoleh ASI pertamanya, membangun kasih sayang ibu dan bayi, akan meningkatkan produksi ASI yang akhirnya proses menyusu berikutnya akan lebih baik ${ }^{1}$. IMD sudah diperkenalkan satu dekade terakhir di Indonesia namun dalam perkembangannya belum menggembirakan. Data Riskesdas tahun 2018 menunjukan pemberian IMD kurang dari satu jam adalah $83,8 \%$, pemberian IMD $\geq$ dari satu jam adalah $16,2 \%$ sedangkan target IMD di Indonesia adalah 95\%. Menurut UNICEF, angka IMD di Indonesia masih jauh di bawah standar dibandingkan dengan negara lain Asia Tenggara seperti; Myanmar (76\%), Thailand (50\%) dan Filipina (54\%) ${ }^{2}$.

Pemerintah Indonesia mendukung kebijakan WHO dan UNICEF yang merekomendasikan IMD dan pemberian ASI eksklusif sebagai tindakan penyelamatan kehidupan. Bentuk dukungan pemerintah terhadap pelaksanaan IMD terdapat dalam Peraturan Pemerintah No. 33 Tahun 2012 Pasal 9 ayat 1 dan 2. Ayat 1 berbunyi, "Tenaga kesehatan dan penyelenggara fasilitas pelayanan kesehatan wajib melakukan inisiasi menyusui dini terhadap bayi yang baru lahir kepada ibunya paling singkat selama 1 (satu) jam”. Ayat 2 berbunyi, "Inisiasi Menyusui Dini sebagaimana dimaksud pada ayat (1) dilakukan dengan cara meletakkan bayi secara tengkurap di dada atau perut ibu sehingga kulit bayi melekat pada kulit ibu." 3

Penelitian Karen M. Edmon, dkk tahun 2016 di Ghana membuktikan bahwa 16\% kematian neonatus atau bayi yang baru lahir dapat dicegah bila bayi diberi ASI/ kolostrum pada hari pertama. Angka tersebut meningkat $22 \%$ bila bayi melakukan IMD dalam satu jam pertama setelah lahir dan bayi yang diberi kesempatan IMD, delapan kali lebih berhasil dalam pemberian ASI eksklusif selanjutnya ${ }^{3}$.

Salah satu hambatan IMD belum berjalan dengan baik adalah masih kurangnya peran bidan dalam memberi sosialisasi mengenai IMD pada ibu hamil maupun ibu bersalin. Selain itu sebagian besar ibu memilih memberikan susu formula pada bayi pada hari pertama kelahiran sebelum ASI keluar dengan alasan ASI yang keluar pertama kali adalah ASI yang basi dan ada juga beralasan ASI belum keluar atau masih kurang pada hari pertama dan bayi rewel karena kelaparan $^{3}$. Banyak hal yang dapat menghambat pelaksanaan IMD baik faktor internal seperti pengetahuan, sikap, pengalaman dan persepsi ibu, sedangkan faktor eksternal seperti fasilitas kesehatan, petugas penolong persalinan dan peran keluarga ${ }^{4}$.

Pengeluaran ASI dari payudara adalah faktor penting dalam kelanjutan produksi ASI. ASI yang sudah diproduksi dan tidak diisap atau dikeluarkan dari payudara dalam jangka waktu lama, maka inhibitor autokrin sebagai bahan penghambat akan menghentikan sel-sel pembuat ASI untuk memproduksi ASI. Ibu yang jarang atau tidak menyusui bayinya akan menyebabkan refleks prolaktin terhenti sehingga sekresi ASI juga akan terhenti ${ }^{2}$. Sebaliknya ibu yang sering menyusui bayi akan meningkatkan produksi susu 2 kali lipat ${ }^{5}$.

Hormon prolaktin sudah dimulai sejak kehamilan, tetapi adanya efek penekanan progesteron dan estrogen yang disekresikan dalam jumlah sangat besar oleh plasenta dalam uterus mengurangi efek laktogenik prolaktin dan somatomamotropin korionik manusia sehingga tidak adanya laktasi selama kehamilan. Segera setelah bayi dilahirkan, estrogen dan progesteron yang disekresi plasenta hilang sehingga memungkinkan efek laktogenik prolaktin dari kelenjar hipofisis ibu mengambil peranan alamiah dan dengan adanya isapan pada puting susu segera setelah bayi lahir (IMD) mempercepat proses pengeluaran hormon prolaktin ${ }^{6}$. Peran 
Jurnal Kesehatan Terpadu (Integrated Health Journal)

Vol. 12 No. 1, Mei 2021 (30-38)

ISSN 1978-7766 (Print) and ISSN 2597-9566 (Online)

Journal homepage: https://www.jurnalpoltekkesmaluku.com/index.php/JKT

hormon prolaktin sangat penting dalam produksi ASI dan laktasi sedangkan isapan puting pada langkah kelima breast crawl diyakini dapat merangsang pengeluaran hormon prolaktin.

Rumah Sakit Tk II Prof. Dr. J. A. Latumeten Ambon merupakan salah satu rumah sakit rujukan yang ada kota Ambon dengan angka persalinan cukup banyak. Menurut survei pendahuluan didapatkan bahwa jumlah persalinan normal periode bulan Januari sampai Oktober 2016 tercatat 405 persalinan yang terdiri dari primipara sebanyak 108 dan multipara 297. Diketahui pula bahwa pelaksanaan IMD belum rutin dilakukan namun tergantung kondisi dan keinginan pasien. RSUD dr. M. Haulussy merupakan rumah sakit pusat rujukan di Provinsi Maluku dengan jumlah persalinan normal rata-rata 110 orang per bulan. Pelaksanaan IMD rutin dilakukan dan merupakan prosedur tetap pada RSUD dr. M. Haulussy Ambon. Penulis melakukan penelitian pada kedua rumah sakit dengan subjek penelitian di Rumkit Tk II Prof. Dr. J. A. Latumeten sebagai kontrol sedangkan subjek penelitian pada RSUD Dr. M. Haulussy Ambon sebagai kasus dalam melaksanakan IMD.

\section{METODE PENELITIAN}

Jenis penelitian yang digunakan adalah quasi eksperimental dengan post test only design with control group yaitu satu kelompok ibu diberikan perlakuan IMD dan satu kelompok kontrol. Penelitian ini dilakukan untuk melihat pengaruh IMD (variabel terikat) dengan pengeluaran volume ASI (variabel bebas).

Populasi dalam penelitian ini adalah seluruh ibu primigravida yang melahirkan di Rumkit Tk II Prof. Dr. J. A. Latumeten Ambon pada bulan Agustus s/d November 2016 dengan perkiraan persalinan primipara dalam periode bulan Agustus s/d November 2017.

Sampel dalam penelitian ini adalah ibu yang melahirkan anak pertama (Primipara) secara normal (pervagina) yang memenuhi kriteria inklusi. Besar sampel adalah 50.

Teknik pengambilan sampel yang digunakan untuk penelitian ini adalah purposive sampling yaitu pemilihan sampel dengan pertimbangan khusus sehingga layak untuk dijadikan sampel dengan persyaratan sampel yang diperlukan.

Pengolahan data dalam penelitian ini dengan menggunakan bantuan program komputerisasi dan analisis data dengan uji Mann Whitney U Test.

\section{HASIL}

Tabel 1. Distribusi Frekuensi Karakteristik Ibu di Rumkit Tk II Prof. Dr. J. A. Latumeten dan RSUD Dr. M. Haulussy Ambon

\begin{tabular}{|c|c|c|c|c|}
\hline \multirow{3}{*}{ Variabel } & \multicolumn{4}{|c|}{ Kelompok } \\
\hline & \multicolumn{2}{|c|}{ Kasus } & \multicolumn{2}{|c|}{ Kontrol } \\
\hline & $\mathbf{n}$ & $\%$ & $\mathbf{n}$ & $\%$ \\
\hline \multicolumn{5}{|l|}{ Umur } \\
\hline$<20$ Tahun & 5 & 20 & 6 & 24 \\
\hline 20-35 Tahun & 20 & 80 & 19 & 76 \\
\hline \multicolumn{5}{|l|}{ Pendidikan } \\
\hline SD & 0 & 0 & 0 & 0 \\
\hline SMP & 2 & 8 & 1 & 4 \\
\hline SMA & 17 & 68 & 19 & 76 \\
\hline Diploma/S1 & 6 & 24 & 5 & 20 \\
\hline \multicolumn{5}{|l|}{ Pekerjaan } \\
\hline Tidak Bekerja & 21 & 84 & 20 & 80 \\
\hline PNS & 1 & 4 & 3 & 12 \\
\hline Swasta & 3 & 14 & 2 & 8 \\
\hline
\end{tabular}


Jurnal Kesehatan Terpadu (Integrated Health Journal)

Vol. 12 No. 1, Mei 2021 (30-38)

ISSN 1978-7766 (Print) and ISSN 2597-9566 (Online)

Journal homepage: https://www.jurnalpoltekkesmaluku.com/index.php/JKT

Karakteristik sampel berdasarkan umur dikelompokan menjadi 2 kelompok masingmasing umur $<20$ tahun dan 20-35 tahun. Berdasarkan tabel 1 dapat dilihat bahwa dari 50 sampel sebagian besar berusia 20-35 tahun yaitu kelompok yang IMD sebanyak 20 orang (80\%) dan kelompok yang tidak IMD sebanyak 19 orang $(76 \%)$.

Karakteristik pendidikan dikelompokan menjadi 4 yaitu SD, SMP/sederajat, SMA/sederajat dan Diploma/ S1. Pada tabel 1 dapat dilihat bahwa dari 50 sampel sebagian besar berpendidikan SMA, yang melakukan IMD sebanyak 19 orang (76\%) dan yang tidak melakukan IMD sebanyak 17 orang (68\%).

Berdasarkan pekerjaan responden dikelompokkan menjadi 3 yaitu tidak bekerja, PNS dan Swasta. Dapat dilihat bahwa sebagian besar sampel tidak bekerja sebanyak 20 orang (80\%) untuk kelompok yang melakukan IMD dan 21 orang (84\%) untuk kelompok yang tidak melakukan IMD.

Tabel 2. Distribusi Frekuensi Karakteristik Bayi di Rumkit Tk II Prof. Dr. J. A. Latumeten dan RSUD Dr. M. Haulussy Ambon

\begin{tabular}{ccccc}
\hline & \multicolumn{4}{c}{ Kelompok } \\
\cline { 2 - 5 } Variabel & \multicolumn{2}{c}{ Kasus } & \multicolumn{2}{c}{ Kontrol } \\
\cline { 2 - 5 } & $\mathbf{N}$ & $\mathbf{\%}$ & $\mathbf{n}$ & $\mathbf{\%}$ \\
\hline Jenis Kelamin bayi & & & & \\
Perempuan & 8 & 32 & 15 & 60 \\
Laki-laki & 17 & 68 & 10 & 40 \\
\hline Berat Badan Bayi & & & & \\
$<2500$ gram & 0 & 0 & 0 & 0 \\
2500-4000 gram & 25 & 100 & 25 & 100 \\
\hline Panjang Badan Bayi & & & & \\
$<50 \mathrm{~cm}$ & 21 & 84 & 21 & 84 \\
$\geq 50 \mathrm{~cm}$ & 4 & 16 & 4 & 16 \\
\hline
\end{tabular}

Karakteristik berdasarkan jenis kelamin bayi dikelompokan menjadi perempuan dan laki-laki. Berdasarkan tabel 1 terlihat bayi laki-laki lebih banyak pada kelompok yang melakukan IMD sebanyak 17 orang (68\%) dan perempuan lebih banyak pada kelompok melakukan IMD sebanyak 15 orang $(60 \%)$.

Berdasarkan berat badan lahir, bayi dikelompokan menjadi 2 yaitu berat badan $<2500$ gram dan 2500-4000 gram. Terlihat bahwa baik kelompok yang melakukan IMD maupun tidak melakukan IMD berat badan bayinya antara 2500-4000 gram. Berdasarkan panjang badan bayi, tampak bahwa sebagian besar bayi dengan panjang badan $<50 \mathrm{~cm}$ yaitu 21 orang (84\%) baik pada kelompok IMD maupun yang tidak IMD.

Tabel 3. Distribusi Frekuensi Responden menurut Bentuk Puting Susu di Rumkit Tk II Prof. Dr. J. A. Latumeten dan RSUD Dr. M. Haulussy Ambon

\begin{tabular}{lcccc}
\hline \multirow{2}{*}{ Variabel } & \multicolumn{4}{c}{ Kelompok } \\
\cline { 2 - 5 } & \multicolumn{2}{c}{ Kasus } & \multicolumn{2}{c}{ Kontrol } \\
\cline { 2 - 5 } & $\mathbf{n}$ & \% & n & \% \\
\hline Bentuk Putting Susu & 0 & 0 & 4 & 18 \\
Datar & 25 & 100 & 21 & 84 \\
Terbentuk & & &
\end{tabular}

Karakteristik responden berdasarkan bentuk puting susu terbagi 2 yaitu puting susu datar dan terbentuk. Bedasarkan tabel 1 terlihat bahwa semua responden (100\%) pada kelompok 
Jurnal Kesehatan Terpadu (Integrated Health Journal)

Vol. 12 No. 1, Mei 2021 (30-38)

ISSN 1978-7766 (Print) and ISSN 2597-9566 (Online)

Journal homepage: https://www.jurnalpoltekkesmaluku.com/index.php/JKT

IMD puting susunya terbentuk/menonjol dan sebagian besar responden yaitu 21 (84\%) kelompok tidak IMD puting susunya terbentuk/menonjol.

Tabel 4. Distribusi Frekuensi Responden menurut Lamanya IMD di Rumkit Tk II Prof. Dr. J. A. Latumeten dan RSUD Dr. M. Haulussy Ambon

\begin{tabular}{lcccc}
\hline \multirow{2}{*}{ Variabel } & \multicolumn{4}{c}{ Kelompok } \\
\cline { 2 - 5 } & \multicolumn{2}{c}{ Kasus } & \multicolumn{2}{c}{ Kontrol } \\
\cline { 2 - 5 } & $\mathbf{n}$ & $\mathbf{\%}$ & $\mathbf{n}$ & $\boldsymbol{\%}$ \\
\hline Tidak Dilakukan & 0 & 0 & 25 & 100 \\
$<60$ & 16 & 64 & 0 & 0 \\
$\geq 60$ & 9 & 36 & 0 & 0 \\
\hline
\end{tabular}

Karakteristik waktu atau lamanya IMD dilakukan terlihat bahwa 16 orang (64\%) melakukan IMD $<60$ menit dan 9 orang (36\%) melakukan IMD $\geq 60$ menit.

Tabel 5. Distribusi Frekuensi Responden menurut Pengeluaran Volume ASI pada hari Ketiga di Rumkit Tk II Prof. Dr. J. A. Latumeten dan RSUD Dr. M. Haulussy Ambon

\begin{tabular}{ccccc}
\hline \multirow{2}{*}{ Variabel } & \multicolumn{4}{c}{ Kelompok } \\
\cline { 2 - 5 } & \multicolumn{3}{c}{ Kasus } & \multicolumn{3}{c}{ Kontrol } \\
\cline { 2 - 5 } & $\mathbf{n}$ & $\mathbf{\%}$ & $\mathbf{n}$ & $\mathbf{\%}$ \\
\hline Kurang & 1 & 4 & 19 & 76 \\
Cukup & 14 & 56 & 6 & 24 \\
Banyak & 10 & 40 & 0 & 0 \\
\hline
\end{tabular}

Karakteristik berdasarkan pengeluaran volume ASI pada hari ketiga postpartum dikelompokan menjadi kurang $(<22 \mathrm{ml})$, cukup $(22-27 \mathrm{ml})$, banyak $(>27 \mathrm{ml})$. Berdasarkan tabel 1 terlihat bahwa 1 orang (4\%) mempunyai volume ASI kurang pada kelompok yang IMD sedangkan kelompok yang tidak IMD terdapat 19 orang $(76 \%)$ yang volume ASI kurang. Terdapat 14 orang (56\%) volume ASI cukup pada kelompok IMD, 6 orang (24\%) volume ASI cukup pada kelompok tidak IMD dan ada 10 orang (40\%) dari kelompok IMD yang volume ASI banyak.

Tabel 6. Hasil Analisis Mann-Whitney Pengaruh IMD terhadap Pengeluaran Volume ASI pada Primipara di Rumkit Tk II Prof. DR. J. A. Latumeten dan RSUD dr. M. Haulussy Ambon

\begin{tabular}{lccc}
\hline \multicolumn{2}{c}{ Mann-Whitney } & Mean Rank & p-value \\
\hline $\begin{array}{l}\text { Volume ASI } \\
\text { IMD }\end{array}$ & \multirow{2}{*}{57.500} & 35.70 & \multirow{2}{*}{0.000} \\
Tidak IMD & & 15.30 & \\
\hline Lama IMD & & & \\
<60 Menit & \multirow{2}{*}{12.500} & 37.50 & 0.000 \\
$\geq 60$ Menit & 13.50 & \\
\hline
\end{tabular}

Berdasarkan tabel 6 dapat dilihat bahwa hasil uji statistik dengan Mann-Whitney test diperoleh nilai $p=0.000<$ dari nilai $\alpha=0.05$. Hal ini menunjukan ada pengaruh yang bermakna antara pengeluaran volume ASI pada kelompok ibu yang melakukan IMD dan tidak IMD. 
Jurnal Kesehatan Terpadu (Integrated Health Journal)

Vol. 12 No. 1, Mei 2021 (30-38)

ISSN 1978-7766 (Print) and ISSN 2597-9566 (Online)

Journal homepage: https://www.jurnalpoltekkesmaluku.com/index.php/JKT

\section{BAHASAN}

\section{Karakteristik Responden}

Umur kelompok intervensi dan kontrol yang menjadi responden pada penelitian ini berusia $<20$ tahun dan 20-35 tahun. Rata-rata umur tergolong remaja akhir dan semuanya adalah primipara sehingga belum memiliki pengalaman maupun pengetahuan dalam melaksanakan IMD. Bertambahnya umur seseorang diharapkan dapat memberikan pengalaman dan pengetahuan seseorang, sehingga umur merupakan faktor yang dapat mempengaruhi pengetahuan seseorang ${ }^{7}$. Dalam penelitian ini, umur tidak menjadi kendala untuk terlaksananya IMD, karena ibu sangat kooperatif dapat menerima informasi yang diberikan oleh petugas.

Tingkat pendidikan turut menentukan mudah tidaknya seseorang memahami dan menyerap informasi. Dari 900 orang ibu di Jabodetabek didapatkan 70.4\%, tak pernah mendapatkan informasi tentang manfaat pemberian ASI eksklusif khususnya tentang IMD sehingga mempengaruhi pengetahuan, sikap dan perilaku ibu tentang pemberian ASI. Hal ini didukung oleh hasil penelitian bahwa adanya hubungan yang bermakna antara pendidikan dengan pemberian ASI dini yaitu responden yang berpendidikan tinggi lebih banyak melakukan IMD dibandingkan responden berpendidikan rendah ${ }^{1}$.

Responden yang melaksanakan IMD maupun tidak melaksanakan IMD kebanyakan dengan status tidak bekerja atau hanya sebagai ibu rumah tangga dan semua adalah primigravida dengan proporsi jumlah responden yang melaksanakan IMD lebih banyak dibanding dengan responden yang tidak IMD. Hal ini menunjukan bahwa status pekerjaan bukanlah suatu hal yang dapat menghambat pelaksanaan IMD saat ibu melahirkan.

Responden yang melaksanakan IMD maupun tidak melaksanakan IMD semua melahirkan anak dengan berat badan 2500-4000 gram. Salah satu indikator dilakukan IMD adalah keadaan ibu dan bayi baik, berat bayi lahir memenuhi standar berat lahir normal yaitu 2500-4000 gram. Kategori yang dipakai adalah berat bayi lahir normal sehingga tidak memberikan pengaruh yang bermakna terhadap pelaksanaan IMD.

Berat bayi dibawah normal $(<2500$ gram), tidak dapat dilakukan IMD karena membutuhkan penanganan khusus. Berat bayi lahir rendah biasanya disebabkan karena Pertumbuhan Janin Terhambat (PJT), asfiksia dan komplikasi lainnya sehingga ketika lahir membutuhkan penanganan khusus dan tidak dianjurkan untuk melakukan IMD.

Bentuk puting susu pada ibu yang melaksanakan IMD, sebanyak 25 orang (100\%), memiliki puting susu yang terbentuk dan 25 ibu yang tidak IMD, 21 (84\%), juga memiliki puting susu yang terbentuk.

Bentuk puting susu bukanlah suatu hal yang menjadi penghalang untuk melaksanakan IMD karena pelaksanaan IMD tidak hanya berorientasi pada penghisapan puting susu secara dini tetapi masih banyak komponen penting yang bermanfaat bagi ibu dan bayi diantaranya mencegah terjadinya hipotermi pada bayi dengan skin to skin contact. Selain itu dapat merangsang pengeluaran hormon oksitosin yang dapat mencegah terjadinya atonia pada ibu sehingga mengurangi resiko perdarahan, serta mempercepat percepatan pelepasan plasenta. ${ }^{9}$

IMD adalah bayi dapat diletakkan di atas dada ibu segera setelah lahir minimal 60 menit dan terjadi skin to skin contact dan tidak menyodorkan bayi ke puting susu dan bayi menyusu selama 1 jam atau lebih. Apabila bayi diletakkan di dada ibu kurang dari satu jam hal itu merupakan praktik IMD yang tidak sesuai dengan standar pelaksanaan IMD. Waktu menyusu mulai bayi diletakkan di dada ibu sampai bayi meraih puting dan menyusui sangat mempengaruhi produksi ASI.

Pemberian ASI sedini mungkin melalui IMD dan sesering mungkin menyusui bayinya akan merangsang otot polos payudara untuk berkontraksi yang kemudian akan merangsang susunan saraf di sekitarnya dan meneruskan rangsangan tersebut ke otak. Otak akan memerintahkan kelenjar hipofise menurunkan kadar hormon estrogen dan progesteron. 
Jurnal Kesehatan Terpadu (Integrated Health Journal)

Vol. 12 No. 1, Mei 2021 (30-38)

ISSN 1978-7766 (Print) and ISSN 2597-9566 (Online)

Journal homepage: https://www.jurnalpoltekkesmaluku.com/index.php/JKT

Pengeluaran hormon pituatari yang lebih banyak akan mempengaruhi kuatnya kontraksi otot-otot polos payudara dan uterus. Kontraksi otot polos payudara berfungsi untuk produksi ASI.

Kondisi yang terlihat selama ini di tempat pelayanan kesehatan khususnya di ruang bersalin, jumlah perawat atau bidan yang bertugas sangat terbatas sementara masih harus menolong persalinan yang lain ditambah tugas yang lain yang harus diselesaikan, sehingga proses atau tahapan persalinan setiap ibu hamil harus diselesaikan segera mungkin termasuk melewatkan proses IMD. Namun demikian sebagai petugas di kamar bersalin sudah menjadi kewajiban untuk menolong persalinan sesuai dengan standar ${ }^{1}$.

UNICEF dan pemerintah Indonesia telah mencanangkan IMD sebagai bagian dari upaya mengoptimalisasi pemberian ASI secara eksklusif. Kebijakan pemerintah dalam rangka mengimplementasikan IMD sangat nyata dengan keluarnya PERMENKES No. HK. 02.02/MENKES/149/2010 tentang penyelenggaraan praktik dalam menolong persalinan yang menyatakan bahwa seorang bidan harus melakukan IMD dan promosi ASI secara eksklusif dan juga dengan terbitnya buku panduan Asuhan Persalinan Normal (APN), 60 langkah, dan IMD merupakan langkah ke 48 dalam APN. ${ }^{10}$

\section{Perbedaan rata-rata pengeluaran ASI hari ketiga postpartum ibu yang melakukan IMD dan tidak melakukan IMD.}

Hasil uji Mann Whitney, didapatkan nilai $p=0.000$ dari $<\alpha=0.05$, dengan rata-rata pengeluaran ASI ibu yang melakukan IMD adalah $35.70 \mathrm{ml}$ sedangkan ibu yang tidak melakukan IMD hanya $13.50 \mathrm{ml}$, hal ini membuktikan adanya perbedaan yang signifikan rata-rata pengeluaran ASI pada hari ke tiga postpartum antara ibu yang melakukan dan tidak melakukan IMD.

Hasil penelitian ini membuktikan bahwa IMD sangat memberikan manfaat bagi ibu dan bayi dalam proses laktasi dan khususnya pemenuhan kebutuhan ASI bagi bayi. Oleh karena itu IMD harus diterapkan pada semua persalinan normal selama tidak ada komplikasi.

Pada saat bayi mulai mengisap puting susu ketika IMD akan terjadi 2 refleks (prolaktin dan oksitosin), refleks tersebut yang menyebabkkan ASI keluar pada saat yang tepat dengan jumlah yang tepat ${ }^{11}$. Refleks mengisap pada bayi baru lahir mencapai puncaknya pada 2030 menit pertama kelahiran sehingga tidak boleh menunda IMD. Kebijakan tentang IMD ini telah disosialisasikan di Indonesia sejak tahun $2007 .{ }^{12}$

Pengeluaran kolostrum secara normal pada hari pertama dan optimal pada hari ketiga setelah melahirkan dengan jumlah normal kolostrum hari pertama $50 \mathrm{ml}$ dan produksi maksimal pada hari ketiga $>100 \mathrm{ml} .{ }^{13}$ Pengeluaran ASI dari payudara adalah faktor penting dalam kelanjutan produksi ASI, terdapat bahan kimia dalam ASI yang dirancang untuk menghentikan produksi ASI jika tidak digunakan, jika ASI yang sudah diproduksi tidak diisap atau dikeluarkan dari payudara dalam jangka waktu lama, bahan kimia (penghambat), atau inhibitor autokrin ini akan menghentikan sel-sel pembuat ASI memproduksi $\mathrm{ASI}^{3}$.

Kebutuhan ASI pada hari ketiga kelahiran bayi adalah 22-27 ml, ibu yang sering menyusui bayinya akan memproduksi dan mengeluarkan ASI yang banyak sedangkan ibu yang jarang atau tidak menyusui bayinya akan menyebabkan refleks prolaktin terhenti, sekresi ASI juga akan terhenti, alveoli akan meluruh kemudian seiring siklus menstruasi alveoli akan terbentuk kembali, mekanisme ini mencegah penuhnya payudara yang diperlukan ketika bayi berhenti menyusu atau tidak menyusu sama sekali. Proses menyusu ataupun diperah untuk mengeluarkan ASI inhibitor autokrin tetap dikeluarkan sehingga produksi ASI terus berlanjut. Intensitas yang tinggi pada bayi untuk menyusu akan membuat produksi ASI semakin banyak, sebaliknya jika bayi jarang atau tidak menyusu akan menyebabkan produksi ASI kurang. ${ }^{14}$ Selain itu perasaan ibu yang bahagia, senang, 
Jurnal Kesehatan Terpadu (Integrated Health Journal)

Vol. 12 No. 1, Mei 2021 (30-38)

ISSN 1978-7766 (Print) and ISSN 2597-9566 (Online)

Journal homepage: https://www.jurnalpoltekkesmaluku.com/index.php/JKT

menyayangi bayinya, memeluk, mencium dan mendengarkan bayinya menangis dapat melancarkan pengeluaran ASI. ${ }^{15}$

\section{SIMPULAN}

Pelaksanaan IMD pada kelompok kasus adalah 100\% sedangkan pada kelompok kontrol tidak dilakukan. Lama waktu pemberian IMD adalah $64 \%$ belum sesuai standar dan $36 \%$ sesuai standar. Volume pengeluaran ASI pada hari ketiga setelah IMD dikategorikan cukup (56\%) dan banyak 40\%, sedangkan ibu yang tidak IMD 76\% volume ASI kurang. Ditemukan adanya perbedaan antara volume ASI pada ibu yang IMD dan tidak IMD. Ditemukan adanya pengaruh yang kuat antara pengeluaran ASI pada ibu yang melakukan IMD dan tidak melakukan IMD. Oleh karena itu, pelaksanaan IMD mempengaruhi volume ASI.

\section{SARAN}

Diharapkan peran serta petugas kesehatan/ bidan dalam memberikan informasi kepada masyarakat terutama pada pada ibu sebelum melahirkan dan pendampingnya tentang pentingnya IMD dan proses pelaksanaannya dengan memberdayakan mahasiswa Kebidanan, Keperawatan dan Kedokteran yang sedang praktik untuk mensosialisasikan keberhasilan IMD. Diharapkan bidan lebih menekankan IMD bukan pada pencapaian puting susu tetapi lama kontak skin to skin, sesuai standar minimal yaitu 1 jam. Untuk Rumkit Tk II Prof. Dr. J. A. Latumeten diharapkan dapat melaksanakan IMD sebagai salah satu prosedur tetap di kamar bersalin.

\section{UCAPAN TERIMA KASIH}

Penulis menyampaikan ucapan terima kasih kepada yang terhormat:

1. Direktur Politeknik Kesehatan Kemenkes Maluku yang telah memberikan kesempatan penulis untuk melaksanakan penelitian.

2. Direktur Rumkit Tk II Prof. Dr. J. A. Latumeten dan Direktur RSUD Dr. M. Haulussy Ambon yang telah memberikan izin bagi penulis untuk melaksanakan penelitian.

3. Kepala Ruangan Kebidanan Rumkit Tk II Prof. Dr. J. A. Latumeten dan RSUD Dr. M. Haulussy Ambon serta para peneliti pendamping yang telah membantu dalam pelaksanan penelitian ini.

\section{RUJUKAN}

1. Roesli U. Inisiasi menyusu dini. Pustaka bunda. Jakarta; 2008.

2. Badan Litbangkes. https://www.litbang.kemkes.go.id/laporan-riset-kesehatan-dasar-riskesdas/:2018.

3. Kemenkes RI. Riset Kesehatan Dasar. Batlibang Kemenkes RI Jakarta: 2018.

4. Mantasia. Pengaruh Inisiasi Menyusu Dini Terhadap Kadar Hormon Oksitosin dan Proses Involusio Uteri pada Ibu Post Partum Resiko Tinggi Di RSUD H. Padjonga Dg Ngalekab Takalar. Jurnal Voice Midwifery Vol. 07 No. 09; 2017. diakses tanggal 20 Nopember 2018

5. Egliand Newton G.E. 2014. The influence of the number of breast feeding on milk production. American academy of pediatrics. Diakses tanggal 21 Oktober 2018

6. Yulianti. Inisiasi Menyusu Dini. Trans Info Media.Jakarta; 2010

7. Camille E.Powe, AB. et al. Effects of Recombinant Human Prolactin on Breast Milk Composition. 2011. Pediatrics.appublications.org. diakses tanggal 20 Oktober 2018.

8. Notoatmodjo S. Promosi Kesehatan dan Perilaku Kesehatan. PT Rineka Cipta. Jakarta; 2012

9. Paige Smith H.. Early breastfeeding experience adolescents mother. International breastfeeding Landon; 2012.diakses tanggal 27 Oktober 2018.

10. JNPK-KR. Asuhan Persalinan Normal. Depkes RI Jakarta; 2012. 
Jurnal Kesehatan Terpadu (Integrated Health Journal)

Vol. 12 No. 1, Mei 2021 (30-38)

ISSN 1978-7766 (Print) and ISSN 2597-9566 (Online)

Journal homepage: https://www.jurnalpoltekkesmaluku.com/index.php/JKT

11. Bobak, Lowdermilk, Jensen. Buku Ajar Keperawatan Maternitas, Alih Bahasa Wijayarini. EGC. Jakarta; 2004.

12. Roesli U. Mengenal ASI Eksklusif.PT Pustaka Pembangunan Swadaya Nusantara. Jakarta; 2013

13. Prasetyono, Dwi Sunar. Buku Pintar ASI eksklusif Pengenalan Praktik dan Kemanfaatannya. Diva Press. Yogyakarta; 2009

14. Maryunani Anik.Inisiasi Menyusu Dini.Trans Info Media. Jakarta; 2012

15. Helmi Yenie dan Mugiati. Hubungan Inisiasi Menyusu Dini Dengan Waktu Pengeluaran Kolostrum. Jurnal keperawatan Volume XI No 2 ; 2015. diakses tanggal 15 Oktober 2018

16. Peraturan Pemerintah Republik Indonesia. Nomor 33 tahun 2012 tentang Pemberian Air Susu Ibu Eksklusif. Jakarta

17. Dahlan Sapiyuddin. Statistik untuk kedokteran dan kesehatan. Salemba Medika, Jakarta; 2014

18. Kementerian Kesehatan RI. Data dan Informasi Profil Kesehatan Indonesia 2017. Kementerian Kesehatan RI.Jakarta;2018 